\title{
PENGARUH GAYA KEPEMIMPINAN TERHADAP KETERIKATAN KERJA PEGAWAI PUSAT PENELITIAN DAN PENGEMBANGAN SUMBER DAYA AIR
}

\author{
THE INFLUENCE OF LEADERSHIP STYLE TO WORK ENGAGEMENT \\ AT THE CENTRE FOR WATER RESOURCES RESEARCH AND DEVELOP- \\ MENT
}

\author{
Metha Djuwita Supriatna \\ Sekolah Tinggi Ilmu Administrasi Lembaga Administrasi Negara Bandung \\ email : methadjuwita@gmail.com
}

\begin{abstract}
Abstrak
Tujuan dari Penelitian ini adalah menganalisis pengaruh gaya kepemimpinan terhadap keterikatan kerja pegawai Pusat Penelitian dan Pengembangan Sumber Daya Air, Kementerian Pekerjaan Umum dan Perumahan Rakyat. Metode yang digunakan yaitu metode deskriptif dan verifikatif. Pengumpulan data primer dilakukan dengan menggunakan kuesioner. Responden dalam penelitian ini adalah 100 orang pegawai negeri sipil kantor pusat Puslitbang Sumber Daya Air yang diambil secara proporsional. Adapun metode penentuan sampel yang digunakan adalah convenience sampling. Hasil penelitian menunjukkan bahwa gaya kepemimpinan situasional di Puslitbang SDA termasuk kedalam gaya kepemimpinan selling. Studi ini menunjukkan bahwa keterikatan kerja di Puslitbang SDA termasuk dalam kategori tinggi. Selain itu, hasil analisis regresi sederhana pada penelitian ini mengungkap pengaruh signifikan gaya kepemimpinan terhadap keterikatan kerja. Keragaman varian penjelas keterikatan kerja pegawai yang ditinjau dari gaya kepemimpinan tergolong moderat, sehingga hal ini membuka peluang yang lebih besar untuk studi lebih lanjut di masa mendatang.
\end{abstract}

Kata Kunci: gaya kepemimpinan, keterikatan kerja, pegawai

\begin{abstract}
The purpose of this research was to analyze the effect of leadership style to work engagement at the Centre for Water Resources Research and Development, Ministry of Public Works and Public Housing. Descriptive and verivicative method are used in this study, with data used in this research was collected by using questionnaire. The respondents were 100 civil servant officer of the Centre for Water Resources Research and Development selected proportionally from each unit of the Centre. The sampling method was convenience sampling. The result of this research showed that situational leadership style at the Centre is selling dimension of leadership style. Findings show that work engagement at the Centre is relatively high. As expected, there is significant effect of the leadership style on work engagement. The relatively medium variance founded from linier effect of leadership styles on work engagement. This implies on the relevance and need for further studies in the future.
\end{abstract}

Keywords: leadership style, work engagement, civil servant officer 


\section{PENDAHULUAN}

Organisasi yang tumbuh berkembang dengan baik akan menitikberatkan fokusnya pada sumber daya manusia guna menjalankan fungsinya dengan optimal, khususnya dalam menghadapi dinamika perubahan yang terjadi. Salah satu upaya yang dilakukan Pemerintah dalam menghadapi dinamika tersebut adalah dengan berupaya menciptakan lingkungan kerja yang efektif serta optimal. Dalam prosesnya pemerintah berupaya menciptakan perubahan organisasi yang mempengaruhi jajaran dibawahnya, termasuk pegawai Pusat Penelitian dan Pengembangan Sumber Daya Air (Puslitbang SDA). Puslitbang SDA merupakan satu dari empat institusi penelitian dan pengembangan dibawah Badan Penelitian dan Pengembangan, Kementerian Pekerjaan Umum dan Perumahan Rakyat. Adapun tugas pokok yang dimiliki oleh Puslitbang SDA mencakup pelaksanaan penelitian, pengembangan, serta penerapan ilmu pengetahuan dan teknologi di bidang sumber daya air.

Kajian yang dilakukan Society for $\mathrm{Hu}$ man Resource Management menjelaskan bahwa kunci sukses strategi SDM dalam memaksimalkan human capital adalah dengan meningkatkan keterikatan kerja pegawai (SHRM, 2013a). Oleh karena itu keterikatan kerja bersifat penting bagi organisasi. Dalam hal ini pegawai yang memiliki tingkat keterikatan kerja yang tinggi akan menunjukkan peforma terbaik. Hal ini terjadi karena pegawai tersebut menikmati pekerjaan (Baker \& Ball 2010; dalam Deviyanti \& Sasono 2015). Perlu diketahui bahwa keterikatan kerja berbeda dengan komitmen organisasi. Komitmen organisasi menggambarkan sejauh mana pegawai memilih untuk bersama organisasinya dan berkomitmen untuk mencapai tujuan perusahaan (Kreitner \& Kinicki, 2010; dalam Muliawaty, 2014). Komitmen organisasi berkaitan dengan sikap seseorang dan kedekatan dengan organisasi. Disisi lain, keterikatan kerja bukan merupakan sikap, melainkan suatu tingkatan dimana individu memiliki perhatian yang lebih dalam menjalankan peran di dalam lingkungan organisasi (Saks, 2006; dalam Ayuningtias, 2013).

Studi yang dilakukan Gallup (2013) mengungkap bahwa keterikatan kerja yang semakin tinggi akan mengurangi jumlah absensi dan turnover pegawai, insiden kecelakaan di tempat kerja dan sebagainya. Dalam perspektif pemasaran tingginya keterikatan kerja pegawai akan meningkatkan jumlah pelanggan, meningkatkan produktivitas dan profitabilitas pegawai. Macey (2008) dalam Ayuningtias (2013) menyatakan bahwa pegawai yang engaged akan memiliki keinginan untuk terikat yang menimbulkan gairah akan pekerjaannya, engaged dengan pekerjaannya, bersedia untuk mengorbankan lebih banyak tenaga dan waktu demi 
pekerjaannya, dan menjadi lebih proaktif dalam mencapai tujuan pekerjaannya. Secara umum, pegawai yang engaged cenderung bekerja lebih keras dengan meningkatkan upaya dan energi yang terfokus pada tujuan organisasi, dibandingkan pegawai yang not engaged.

Menurut Schaufeli \& Bekker (2003), keterikatan kerja adalah hal positif terkait pemenuhan kondisi pekerjaan yang ditandai dengan semangat (vigor), dedikasi (dedication), dan absorpsi (absorption). Semangat ditandai oleh iklim kerja yang penuh energi dan ketahanan mental serta kemauan untuk berupaya lebih dalam bekerja dan bertahan walaupun mengalami banyak kesulitan. Dedikasi mengacu pada pegawai yang engaged penuh terhadap pekerjaannya, dan merasakan kepentingan, antusiasme, inspirasi, kebanggaan, dan tantangan dalam pekerjaannya. Absorpsi ditandai dengan iklim yang penuh konsentrasi dan keasyikan dalam melaksanakan pekerjaan, waktu cepat berlalu dan sulit untuk melepaskan pekerjaan tersebut. Ketiga dimensi ini dijadikan acuan oleh Schaufeli dalam mengembangkan sebuah alat ukur UWES (Ultretch Work Engagement Scale) yang sudah terbukti valid dan reliabel serta mayoritas digunakan di beberapa negara (Demerouti, Mostert, \& Bakker 2010).

Berdasarkan hasil observasi keterikatan kerja di Kantor Pusat Puslitbang SDA, menunjukkan indikasi yang terjadi di lapangan yaitu terdapat pegawai yang memperpanjang waktu istirahat, serta mengisi waktu kerja dengan aktivitas lain di luar pekerjaan. Hal tersebut merupakan tindakan indisipliner yang mengindikasikan kecenderungan pegawai relatif tidak engaged terhadap organisasi. Terkait dengan dimensi keterikatan kerja yang terdiri dari semangat, dedikasi, dan absorpsi, jika dikaitkan dengan tindakan indisipliner tersebut, maka dapat disimpulkan bahwa masih ada pegawai yang memiliki semangat kerja rendah yang menunjukkan dedikasi pegawai yang cenderung rendah, serta absorpsi yang rendah dimana pegawai dinilai kurang fokus terhadap pekerjaannya.

Menurut publikasi SHRM (2014), outcomes keterikatan kerja dipengaruhi oleh cara pemimpin organisasi itu sendiri dalam menangani masalah keterikatan kerja. Hasil penelitian Dale Carnegie (2012b) menunjukkan bahwa diantara banyak faktor yang berpengaruh pada keterikatan kerja, tiga kunci utama pendorong keterikatan kerja yang telah diidentifikasi, yaitu (1) hubungan dengan atasan langsung, (2) percaya pada kemampuan pimpinan, serta (3) kebanggaan dalam bekerja bagi perusahaan. Secara implisit, hubungan antara pegawai dengan pimpinan menjadi kunci dari keterikatan kerja (Dale Carnegie, 2012b). Sikap dan tindakan atasan langsung dapat meningkatkan keterikatan kerja atau dapat menciptakan suasana dimana seorang pegawai menjadi actively disengaged. 
Melalui sikap dan tindakan pemimpin yang positif, dapat membangun budaya engagement yang melibatkan dan menginspirasi seluruh pegawai. Keberadaan pemimpin menjadi mutlak dalam organisasi untuk mengkoordinir seluruh aktivitas kelompok, serta mengarahkan seluruh individu yang berada di dalamnya untuk mencapai tujuan organisasi. Oleh karena itu pemimpin dengan gaya kepemimpinannya menentukan strategi organisasi baik jangka panjang maupun jangka pendek.

Pemimpin dalam arti luas didefinisikan sebagai seorang yang memimpin dengan jalan memparkarsai tingkah laku sosial dengan mengatur, mengarahkan, mengorganisir atau mengontrol usaha/upaya orang lain, atau melalui kekuasaan atau posisi. Sedangkan pemimpin dalam pengertian yang terbatas didefinisikan sebagai seorang yang membimbing, memimpin dengan bantuan kualitas-kualitas persuasifnya, dan ekseptansi/penerimaan secara sukarela oleh pengikutnya (Henry 1998; dalam Elmansyah 2011).

Menurut Shane \& Glinow (2010), kepemimpinan adalah proses mempengaruhi, memotivasi, dan mengarahkan orang lain untuk berkontribusi dalam organisasi yang efektif dan sukses sebagai anggota kelompok. Seorang pemimpin harus mengembangkan suatu gaya dalam memimpin bawahannya. Gaya kepemimpinan dapat dirumuskan sebagai suatu pola perilaku yang dibentuk untuk diselaraskan dengan kepentingan-kepentingan organisasi dan pegawai untuk dapat mencapai tujuan yang telah ditetapkan (Nasution 1994; dalam Riyadi 2011). Berbagai teori tentang gaya kepemimpinan telah dijelaskan sebelumnya, tetapi tidak ada ketetapan baku tentang teori mana yang harus diterapkan dalam sebuah organisasi, karena pola kepemimpinan bergantung pada diri pribadi seorang pemimpin, serta bergantung pada situasi dan kondisi lembaga atau organisasi yang dipimpinnya (Elmansyah 2011).

Hersey et al., dalam Jeffrey et al., (2011) berpendapat bahwa gaya kepemimpinan yang efektif adalah gaya kepemimpinan yang dapat beradaptasi dengan tingkat kematangan bawahan. Paul Hersey dan Kenneth $H$. Blanchard mengembangkan model kepemimpinan situasional yang dikenal dengan Hersey and Blanchard's Situational Leadership Model (Wirda \& Azra, 2012). Pada awalnya teori ini disebut the life cycle theory of leadership, yang didasarkan pada anggapan bahwa pemimpin perlu merubah perilaku sesuai dengan tingkat kesiapan atau kematangan bawahan atau pengikut. Hersey dan Blanchard (1982) dalam Riyadi (2011) mengemukakan empat dimensi kepemimpinan situasional:

1) Telling (Mengarahkan)

Gaya telling memiliki ciri yang dapat dikatakan arogan, karena bawahan harus 
mengikuti apa yang dikatakan pimpinan. Komunikasi bersifat satu arah. Seluruh pengambilan keputusan berada pada pimpinan, bawahan hanya sebagai pelaksana tanpa memiliki hak untuk menolak.

\section{2) Selling (Melatih)}

Pimpinan dan bawahan mulai melakukan komunikasi dua arah. Bawahan telah diberikan kesempatan untuk menyumbangkan pikirannya, namun pengambil keputusan masih tetap berada pada pimpinan.

\section{3) Participating (Menggalang Partisipasi)}

Pimpinan dan bawahan bersama-sama berperan memberikan sumbangan pikiran, kemudian didiskusikan bersama dalam proses pengambilan keputusan.

\section{4) Delegating (Mendelegasikan)}

Pimpinan lebih terbuka pada bawahan dan komunikasi bersifat dua arah atau ada umpan balik. Bawahan dibiarkan bertindak sendiri dan menentukan kapan, dimana, dan bagaimana tugas harus dilaksanakan. Pimpinan memberikan kepercayaan penuh kepada bawahan. Kepercayaan dan saling kerja sama antar pimpinan dan bawahan semakin meningkat, walaupun bentuknya secara tidak langsung.

Faktor kunci kepemimpinan situasional yang efektif adalah kemampuan pemimpin mengidentifikasi kematangan individu maupun kelompok yang hendak dipengaruhi untuk selanjutnya menggunakan gaya kepemimpinan situasional yang sesuai. Perilaku bawahan pada dasarnya merupakan tanggapan terhadap gaya kepemimpinan yang diterapkan dalam proses pemecahan masalah dan pengambilan keputusan. Oleh karena itu dalam kepemimpinan situasional, penting bagi setiap pemimpin untuk mengadakan diagnosa dengan baik agar dapat mengubah perilakunya sesuai dengan situasimya, dan mampu memperlakukan bawahan sesuai dengan kebutuhan dan motif yang berbeda-beda (Wahjosumidjo 1984; dalam Mahardayani 2010).

Pada Puslitbang SDA, terdapat satu pejabat tinggi pratama, tujuh administrator, dan empat belas pengawas. Dalam memimpin para staf bawahannya tentunya para pimpinan tersebut memiliki gaya kepemimpinan yang berbeda satu dengan yang lainnya. Berdasarkan hasil observasi gaya kepemimpinan di Puslitbang SDA, gaya kepemimpinan yang dominan digunakan oleh para pimpinan/atasan adalah gaya kepemimpinan situasional. Berdasarkan hasil observasi, indikasi gaya kepemimpinan situasional di Puslitbang SDA yaitu adanya perbedaan pendekatan yang dilakukan oleh pimpinan terhadap pegawainya, seperti perbedaan dalam pemberian penekanan tugas, yang memberikan penekanan tugas terhadap pegawai tertentu dan memberikan kelonggaran penekanan tugas terhadap 
pegawai lainnya. Adapun indikasi lainnya seperti perbedaan dalam proses pengambilan keputusan, dimana terhadap pegawai tertentu pimpinan melibatkannya dalam proses pengambilan keputusan, sedangkan terhadap pegawai lainnya pimpinan tidak melibatkannya dalam pengambilan keputusan.

Kepemimpinan merupakan faktor yang berpengaruh terhadap keterikatan kerja. Dalam membawahi para pegawainya, tentunya para pemimpin memiliki gaya kepemimpinan yang berbeda satu sama lain. Bahkan menurut Dale Carnegie (2012b) hubungan antara atasan langsung dengan pegawai diyakini sebagai faktor utama penentu keterikatan kerja yang pada akhirnya mempengaruhi kinerja individu pegawai itu sendiri. Akan tetapi, fenomena yang ada di Kantor Pusat Puslitbang SDA yaitu gaya kepemimpinan yang dimiliki oleh para atasan langsung belum sepenuhnya mempengaruhi keterikatan kerja. Berkaca pada pentingnya tipe gaya kepemimpinan yang dimiliki atasan, yang dapat berpengaruh pada keterikatan kerja masing-masing pegawai, maka penelitian ini dilakukan untuk menganalisis gaya kepemimpinan serta keterikatan kerja pegawai kantor pusat Puslitbang SDA. Selain itu, penelitian ini pun bertujuan untuk menganalisis implikasi gaya kepemimpinan terhadap keterikatan kerja pada kantor pusat Puslitbang SDA.

\section{METODE PENELITIAN}

Penelitian ini menggunakan metode kuantitif, dengan menganalisis data kuantitatif yang dikategorikan sebagai data primer, berasal dari instrumen penelitian berupa kuesioner yang disebarkan kepada responden penelitian. Desain penelitian yang digunakan adalah cross sectional study, dengan pemilihan lokasi penelitian dilakukan secara purposive sampling.

Populasi dalam penelitian ini adalah pegawai negeri sipil Kantor Pusat Puslitbang Sumber Daya Air yang berjumlah 197 orang. Adapun metode pemilihan sampel yang digunakan adalah convenience sampling. Penentuan jumlah sampel menggunakan rumus Slovin, dan didapatkan jumlah sampel minimal sejumlah 67 orang. Akan tetapi, untuk mencegah ketidakkonsistenan responden dalam memberikan jawaban atas pertanyaan kuesioner, maka dalam penelitian ini digunakan sampel sejumlah 100 orang. Adapun penambahan sampel bagi tiap subpopulasi dilakukan secara proporsional, dimana setiap jumlah sampel dari subpopulasi diberi penambahan sampel sebanyak $49 \%$.

Data yang diperoleh dari penyebaran kuisioner untuk variabel gaya kepemimpinan dan keterikatan kerja berskala ordinal, sedangkan untuk melanjutkan analisis dibutuhkan skala interval. Maka dari itu dilakukan pengukuran skala lanjutan sehingga didapat data berskala 
interval dengan menggunakan Metode Successive Interval (MSI).

Data yang diperoleh kemudian diolah dan dianalisis dengan menggunakan program SPSS for windows. Analisis data dilakukan secara deskriptif dan statistik melalui uji deskriptif dan verifikatif.

Tabel 1

Penentuan Jumlah Sampel

\begin{tabular}{llcccc}
\hline No & Bagian/Bidang/Balai & \multicolumn{4}{c}{ Sampel } \\
\cline { 3 - 6 } & & $\begin{array}{c}\text { Jumlah } \\
\text { Pegawai }\end{array}$ & ni & ni + 49\% (ni) \\
& & & & \\
& & 40 & 20 & 14 & 20 \\
\hline 1 & Tata Usaha & 14 & 7 & 5 & 7 \\
2 & Sumber Daya & & & & \\
& Kelitbangan & & & \\
3 & Standar dan Diseminasi & 16 & 8 & 5 & 8 \\
4 & Program dan Kerjasama & 14 & 7 & 5 & 7 \\
5 & Hidrologi dan Tata Air & 50 & 25 & 17 & 25 \\
6 & Lingkungan Keairan & 28 & 14 & 10 & 14 \\
7 & Bangunan Hidraulik dan & 35 & 18 & 12 & 18 \\
& Geoteknik Keairan & & & & \\
\hline & $\quad$ Total (N) & 199 & 100 & 67 & 100 \\
\hline
\end{tabular}

Analisis data secara deskriptif digunakan untuk memberikan gambaran terkait gaya kepemimpinan dan keterikatan kerja. Metode verifikatif digunakan untuk menguji pengaruh gaya kepemimpinan terhadap keterikatan kerja pegawai di Puslitbang SDA. Teknik analisis data yang dipakai dalam penelitian ini adalah menggunakan analisis regresi linier.

\section{HASIL PENELITIAN}

Pengujian terhadap kuesioner dilakukan sebelum menganalisis data penelitian, melalui uji validitas. Hasil uji validitas terhadap kedua variabel dapat dilihat pada tabel dibawah ini. Berdasarkan tabel tersebut, dapat diketahui bahwa variabel gaya kepemimpinan dalam kuesioner telah mewakili objek yang diteliti.

Tabel 2

Uji Validitas Gaya Kepemimpinan

\begin{tabular}{lllr}
\hline Item & r hitung & r kritis & Keterangan \\
\hline 1 & 0.797 & 0,30 & Valid \\
2 & 0.425 & 0,30 & Valid \\
3 & 0.508 & 0,30 & Valid \\
4 & 0.512 & 0,30 & Valid \\
5 & 0.744 & 0,30 & Valid \\
6 & 0.639 & 0,30 & Valid \\
7 & 0.456 & 0,30 & Valid \\
8 & 0.576 & 0,30 & Valid \\
\hline
\end{tabular}

Uji validitas semua item pernyataan variabel gaya kepemimpinan seluruhnya valid. Kemudian, hasil uji validitas variabel keterikatan kerja dijelaskan pada tabel berikut.

\section{Tabel 3}

\section{Hasil Uji Validitas Keterikatan Kerja}

\begin{tabular}{lccc}
\hline Item & r hitung & r kritis & Keterangan \\
\hline 1 & 0.421 & 0,30 & Valid \\
2 & 0.513 & 0,30 & Valid \\
3 & 0.511 & 0,30 & Valid \\
4 & 0.666 & 0,30 & Valid \\
5 & 0.738 & 0,30 & Valid \\
6 & 0.449 & 0,30 & Valid \\
7 & 0.682 & 0,30 & Valid \\
8 & 0.718 & 0,30 & Valid \\
9 & 0.405 & 0,30 & Valid \\
10 & 0.753 & 0,30 & Valid \\
11 & 0.799 & 0,30 & Valid \\
12 & 0.749 & 0,30 & Valid \\
13 & 0.773 & 0,30 & Valid \\
14 & 0.686 & 0,30 & Valid \\
15 & 0.795 & 0,30 & Valid \\
16 & 0.726 & 0,30 & Valid \\
17 & 0.690 & 0,30 & Valid \\
\hline
\end{tabular}

Dari tabel diatas dapat disimpulkan bahwa pada variabel keterikatan kerja dalam kuesioner telah mewakili objek yang diteliti. 
Uji validitas semua item pernyataan variabel keterikatan kerja seluruhnya valid. Nilai koefisien realibilitas masing-masing variabel dapat dilihat pada Tabel 4 sebagai berikut.

Tabel 4

Hasil Uji Reliabilitas

\begin{tabular}{ccc} 
Variabel & \multicolumn{1}{c}{$\begin{array}{l}\text { Cronbach's } \\
\text { Alpha }\end{array}$} & N of Items \\
\hline GK $(\mathrm{X})$ & .716 & 8 \\
\hline KK $(\mathrm{Y})$ & .916 & 17 \\
\hline
\end{tabular}

Berdasarkan Tabel 4 di atas, didapat hasil nilai reliabilitas untuk variabel gaya kepemimpinan sebesar 0.716, reliabilitas untuk variabel keterikatan kerja sebesar 0.916. Hasil uji validitas dan reabilitas yang dilakukan menunjukkan bahwa semua instrumen pernyataan pada kuesioner variabel gaya kepemimpinan, dan keterikatan kerja pegawai dapat dikategorikan valid dan reliabel.

\section{Tabel 5}

Akumulasi Pernyataan Variabel Gaya Kepemimpinan

\begin{tabular}{lllll}
\hline \multicolumn{1}{c}{ Dimensi } & $\begin{array}{c}\text { Skor } \\
\text { Aktual }\end{array}$ & $\begin{array}{c}\text { Skor } \\
\text { Ideal }\end{array}$ & $\begin{array}{c}\% \\
\text { Skor }\end{array}$ & Kategori \\
\hline Telling & 632 & 1000 & 63,2 & $\begin{array}{l}\text { Cukup } \\
\text { baik }\end{array}$ \\
& & & & Baik \\
Selling & 715 & 1000 & 71,5 & Baik \\
Participating & 683 & 1000 & 68,3 & Baik \\
Delegating & 690 & 1000 & 69,0 & Baik \\
\hline Gaya & 2720 & 4000 & 68,0 & Cukup \\
Kepemimpinan & & & & baik \\
\hline
\end{tabular}

Tabel 5 menunjukkan skor jawaban responden secara keseluruhan mengenai gaya kepemimpinan adalah sebesar $68,00 \%$ dan berada pada rentang antara $>52 \%$ - $68 \%$ yaitu berada dalam kategori cukup baik.
Uji t satu arah dilakukan untuk mengetahui apakah gaya kepemimpinan yang sudah ada termasuk tepat atau tidak. Hipotesis yang diajukan dalam uji t satu arah ini adalah sebagai berikut: (1) $\mathrm{H}_{0} \quad: \mu_{0}=68 \%$ "Gaya kepemimpinan tidak termasuk dalam kategori tepat"; (2) $\mathrm{H}_{1}: \quad \mu_{0}>\quad 68 \% \quad$ "Gaya kepemimpinan termasuk dalam kategori tepat". Dari hasil perhitungan, diketahui bahwa nilai rata - rata sampel $(\bar{x})$ untuk variabel gaya kepemimpinan adalah 68,00. Sedangkan $\mu$ adalah 68 (sebagai batas bawah kriteria Tepat terhadap variabel). Sementara itu simpangan bakunya (s) adalah 10,372. Maka diperoleh $t_{\text {hitung }} 0,00 . t_{\text {tabel }}$ dengan tingkat kepercayaan $95 \%$ dan degree of freedom $(\mathrm{df})=\mathrm{n}-2=100$ $-2=98$ didapatkan nilai 1,66. Dengan kriteria jika $t_{\text {hitung }}>\mathrm{t}_{\text {tabel }}$ maka Ho ditolak, dan jika $\mathrm{t}_{\text {hitung }}<\mathrm{t}_{\text {tabel }}$ maka Ho diterima. Karena $0,00<$ 1,66 maka Ho diterima. Artinya, rata-rata gaya kepemimpinan tidak termasuk dalam kategori tepat.

\section{Tabel 6}

Akumulasi Pernyataan Variabel Keterikatan Kerja

\begin{tabular}{llccl}
\hline \multicolumn{1}{c}{ Dimensi } & $\begin{array}{c}\text { Skor } \\
\text { Aktual }\end{array}$ & $\begin{array}{c}\text { Skor } \\
\text { Ideal }\end{array}$ & $\begin{array}{c}\% \\
\text { Skor }\end{array}$ & Kategori \\
& 2092 & 3000 & 69,73 & Tinggi \\
Semangat & 1875 & 2500 & 75,00 & Tinggi \\
Dedikasi & 2005 & 3000 & 66,83 & Cukup \\
Absorpsi & & & & Tinggi \\
\hline Keterikatan & 5972 & 8500 & 70,26 & Tinggi \\
Kerja & & & & \\
\hline
\end{tabular}

Persentase skor jawaban responden secara keseluruhan mengenai keterikatan kerja 
adalah sebesar 70,26\% dan berada pada rentang antara $>68 \%$ - $84 \%$ yaitu berada dalam kategori tinggi.

Uji hipotesis deskriptif keterikatan kerja dilakukan dengan uji $\mathrm{t}$ satu arah untuk mengetahui apakah keterikatan kerja termasuk tinggi atau tidak tinggi.

Hipotesis yang diajukan dalam uji t satu arah ini adalah sebagai berikut :

(1) $\mathrm{H}_{0}: \mu_{0}=68 \%$ "Keterikatan kerja tidak termasuk dalam kategori tinggi”, dan (2) $\mathrm{H}_{1}$ : $\mu_{0}>68 \%$ "Keterikatan kerja termasuk dalam kategori tinggi”. Diketahui bahwa nilai rata rata sampel $(\bar{x})$ untuk variabel keterikatan kerja adalah 70,30. Sedangkan $\mu$ adalah 68 (sebagai batas bawah kriteria tinggi terhadap variabel). Sementara itu simpangan bakunya (s) adalah 12,66 dan jumlah sampel sebanyak 100 orang. maka diperoleh nilai $t_{\text {hitung }}$ 1,78.Sementara itu, $t_{\text {tabel }}$ dengan tingkat kepercayaan $95 \%$ dan degree of freedom $(\mathrm{df})=$ $\mathrm{n}-2=100-2=98$ didapatkan nilai 1,66 .

Dengan kriteria jika $t_{\text {hitung }}>t_{\text {tabel }}$ maka Ho ditolak, dan jika $t_{\text {hitung }}<t_{\text {tabel }}$ maka Ho diterima. Karena 1,78>1,66 maka Ho ditolak. Hal ini berarti bahwa rata - rata keterikatan kerja berdasarkan pendapat responden termasuk dalam kategori tinggi, hal tersebut sesuai berdasarkan perhitungan persentase skor jawaban responden rata - rata keterikatan kerja termasuk dalam kategori tinggi.

Uji statistik regresi linier sederhana digunakan dalam menganalisis pengaruh variabel Gaya Kepemimpinan $\left(\mathrm{X}_{1}\right)$ terhadap variabel Keterikatan Kerja $\left(\mathrm{X}_{2}\right)$. Berdasarkan perhitungan, dapat disimpulkan bahwa antara variabel Gaya Kepemimpinan $\left(\mathrm{X}_{1}\right)$ dengan Keterikatan Kerja $\left(\mathrm{X}_{2}\right)$ memiliki nilai korelasi 0,684 , artinya berada pada tingkat hubungan yang Kuat.

\section{Tabel 7}

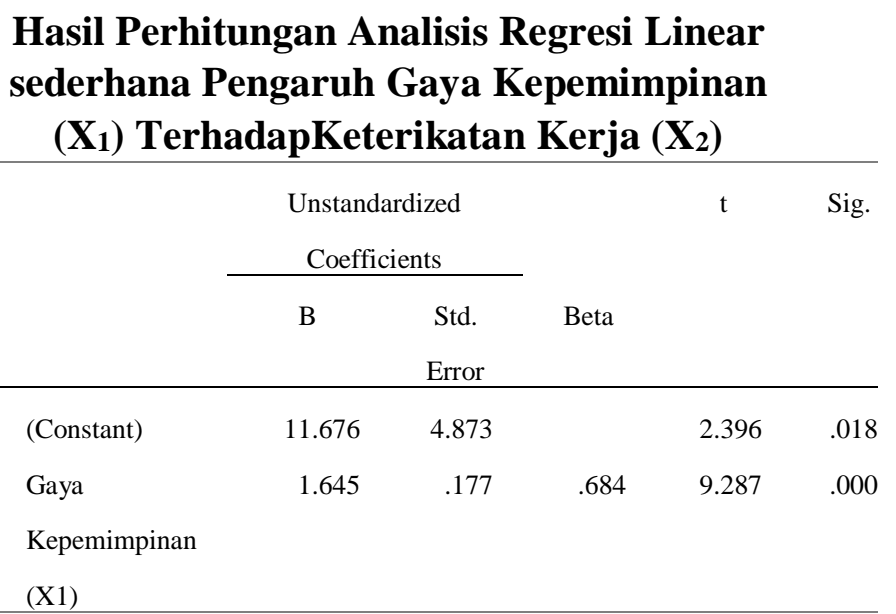

Nilai konstanta (a) sebesar 11,676 yang berarti nilai konstanta positif. Hal ini menunjukkan apabila Gaya Kepemimpinan ( $\left.\mathrm{X}_{1}\right)$ bernilai nol maka pertumbuhan Keterikatan Kerja $\left(\mathrm{X}_{2}\right)$ sebesar 11,676. Koefisien regresi untuk variabel Gaya Kepemimpinan $\left(\mathrm{X}_{1}\right)$ bernilai 1,645 yang berarti mempunyai nilai positif, hal ini menunjukkan hubungan searah antara Gaya Kepemimpinan $\left(\mathrm{X}_{1}\right)$ terhadap Keterikatan Kerja $\left(\mathrm{X}_{2}\right)$.

Analisis koefisien korelasi digunakan untuk mengetahui arah dan kuat hubungan antara kedua variabel. Hasil pengujian koefisien korelasi dan koefisien determinasi, menunjukkan bahwa nilai R2 sebesar 0,468. Nilai ini menunjukkan kontribusi atau 
pengaruh Gaya Kepemimpinan $\left(\mathrm{X}_{1}\right)$ terhadap variabel Keterikatan Kerja $\left(\mathrm{X}_{2}\right)$ sebesar 46,80 persen. Artinya 53,20 persen keterikatan kerja dapat dijelaskan oleh varian lain di luar gaya kepemimpinan.

\section{Tabel 8}

Nilai Koefisien Determinasi

\begin{tabular}{lcc}
\hline Model & R & \multicolumn{2}{c}{ R Square } \\
\hline 1 & $.684^{\mathrm{a}}$ & .468 \\
\hline
\end{tabular}

Pengujian keberartian model menggunakan uji t untuk menguji hipotesis apakah variabel Gaya Kepemimpinan memiliki pengaruh terhadap Keterikatan Kerja. Adapun hipotesis yang diuji sebagai berikut : (1) $\mathrm{H}_{0}: \beta_{1}=0$ "Variabel Gaya Kepemimpinan $\left(\mathrm{X}_{1}\right)$ tidak mempunyai pengaruh terhadap Keterikatan Kerja $\left(\mathrm{X}_{2}\right)$ "; (2) $\mathrm{H}_{1}: \beta_{1} \neq 0$ "Variabel Gaya Kepemimpinan $\left(\mathrm{X}_{1}\right)$ mempunyai pengaruh terhadap Keterikatan Kerja $\left(\mathrm{X}_{2}\right)$ ". Tingkat signifikan yang digunakan untuk penelitian ini adalah $5 \%(0,05)$ dengan derajat kebebasan $\mathrm{df}=\mathrm{n}-\mathrm{k}-1=100-1-1$ $=98$. Dimana didapat $t_{\text {tabel }}$ sebesar 1,66. Nilai statistik uji thitung untuk Gaya Kepemimpinan = 9,287, serta nilai sig (p-value) Gaya Kepemimpinan $=0,000$. Hasil Uji $t$ menunjukkan bahwa dengan tingkat kepercayaan $95 \%$ cukup beralasan untuk menyarankan koefisien regresi Gaya Kepemimpinan berarti dalam model, atau dapat disimpulkan variabel Gaya Kepemimpinan
$\left(\mathrm{X}_{1}\right)$ mempunyai pengaruh terhadap Keterikatan Kerja $\left(\mathrm{X}_{2}\right)$.

\section{PEMBAHASAN}

Responden mempersepsikan gaya kepemimpinan berada dalam kategori cukup baik, dengan demikian dapat disimpulkan bahwa gaya kepemimpinan di Puslitbang SDA secara keseluruhan dalam kategori cukup baik. Di sisi lain masih terdapat kekurangsesuaian antara gaya kepemimpinan yang diterapkan dengan tingkat kesiapan bawahan. Menurut Hersey et al., dalam Jeffrey et al., (2011), gaya kepemimpinan yang efektif adalah gaya kepemimpinan yang dapat beradaptasi dengan tingkat kematangan bawahan.

Rata-rata gaya kepemimpinan dipersepsikan oleh pegawai Puslitbang SDA tidak termasuk dalam kategori tepat. Hal ini disebabkan karena pimpinan di Puslitbang SDA lebih mengedepankan gaya kepemimpinan selling, dimana komunikasi yang terjadi antara pimpinan dan bawahan bersifat dua arah, dan bawahan pun telah diberikan kesempatan untuk menyumbangkan pikirannya. Meskipun pengambil keputusan masih tetap berada pada pimpinan. Dengan tingkat kematangan bawahan yang mayoritas berpendidikan Strata 1, serta masa kerja pegawai yang mayoritas di atas dua puluh tahun. Hal ini menunjukkan bahwa pegawai memiliki kemampuan untuk melaksanakan pekerjaannya, serta memiliki kemauan yang 
tinggi. Oleh karena itu, gaya kepemimpinan yang diterapkan oleh pimpinan belum sesuai dengan tingkat kematangan bawahan di Puslitbang SDA.

Pegawai Puslitbang SDA secara keseluruhan mempersepsikan keterikatan kerja berada dalam kategori tinggi. Dengan demikian dapat disimpulkan bahwa keterikatan kerja di Puslitbang SDA secara keseluruhan dalam kategori tinggi, berdasarkan penilaian terhadap ketiga dimensi yaitu semangat, dedikasi, dan absorpsi. Artinya, pegawai Puslitbang SDA memiliki keinginan untuk menunjukkan peforma terbaiknya. Hal ini terjadi karena pegawai tersebut menikmati pekerjaan yang dilakukan. Dimensi yang memiliki skor tertinggi adalah dedikasi (75\%). Hal ini menunjukkan bahwa pegawai memiliki kemauan yang kuat dalam mengemban pekerjaan yang dimiliki saat ini. Skor tersebut juga menggambarkan bahwa pegawai bangga dan cukup antusias terhadap pekerjaannya.

Temuan penelitian menunjukkan rata rata keterikatan kerja berdasarkan pendapat responden termasuk dalam kategori tinggi. Hasil penelitian menunjukkan bahwa Pegawai Puslitbang SDA memiliki kemauan untuk berupaya lebih terhadap pekerjaannya, antusias dan bangga terhadap pekerjaannya, serta merasa asyik dalam menyelesaikan pekerjaannya.

Hasil penelitian menunjukkan sifat hubungan positif yang linier diantara gaya kepemimpinan atas keterikatan kerja. Gaya Kepemimpinan yang meningkat akan mendorong keterikatan kerja pegawai Puslitbang SDA. Tingkat keragaman hasil ini menunjukkan nilai yang moderat, atau sebesar 46,80 persen. Hal ini menunjukkan lebih dari separuh $(53,20$ persen $)$ varian penjelas atas keterikatan kerja dipengaruhi oleh hal selain gaya kepemimpinan. Hal ini sejalan dengan hasil penelitian Dale Carnegie (2012b) yang menunjukkan bahwa hubungan antara pegawai dengan pimpinan adalah kunci dari keterikatan kerja. Sikap dan tindakan atasan langsung dapat meningkatkan keterikatan kerja atau dapat menciptakan suasana dimana seorang pegawai menjadi actively disengaged.

Carnegie (2012a) menjelaskan bahwa pimpinan merupakan wajah organisasi yang mengatur strategi serta tujuan dan menjalankan perusahaan dalam arah yang benar untuk mencapai visi perusahaan. Melalui sikap dan tindakan pemimpin yang positif, dapat membangun budaya keterikatan yang melibatkan dan menginspirasi seluruh pegawai.

\section{KESIMPULAN DAN SARAN}

Gaya kepemimpinan situasional di Puslitbang SDA lebih termasuk ke dalam kategori gaya kepemimpinan selling. Tingginya nilai gaya kepemimpinan selling, menunjukkan bahwa komunikasi yang terjadi antara pimpinan dan bawahan bersifat dua arah, dan bawahan pun telah diberikan kesempatan 
untuk menyumbangkan pikirannya. Meskipun pengambil keputusan masih tetap berada pada pimpinan. Secara tersirat pegawai memiliki kemampuan untuk melaksanakan pekerjaannya, serta memiliki kemauan yang tinggi.

Keterikatan kerja pegawai Puslitbang SDA yang ditunjukkan oleh semangat, dedikasi, dan absorpsi, dikategorikan tinggi. Pegawai di Puslitbang SDA memiliki kemauan untuk berupaya lebih terhadap pekerjaannya, antusias dan bangga terhadap pekerjaannya, serta merasa asyik dalam menyelesaikan pekerjaannya. Dedikasi memiliki nilai tertinggi jika dibandingkan dimensi keterikatan lainnya. Pegawai merasa pekerjaannya merupakan hal yang penting, menantang, serta antusias terhadap pekerjaan yang dimiliki, dan adanya perasaan bangga bekerja di Puslitbang SDA.

Gaya kepemimpinan mempunyai dampak penting terhadap keterikatan kerja pegawai yang bekerja di Puslitbang SDA. Artinya, peningkatan keterikatan kerja pegawai dapat dijelaskan oleh gaya kepemimpinan. Semakin tepat penerapan gaya kepemimpinan, memiliki arti bahwa pimpinan dapat memahami tingkat kematangan dari individu atau bawahannya yang dipimpinnya, sehingga kesiapan pegawai dalam menerima tugas yang diberikan pimpinan akan lebih baik. Pada akhirnya hal ini akan mendorong peningkatan rasa keterikatan kerja pegawai di Puslitbang SDA.
Jajaran pimpinan atau manajemen disarankan agar lebih menciptakan lingkungan kerja yang lebih kondusif. Terdapat banyak hal yang dapat dilakukan untuk mendukung lingkungan kerja yang kondusif, misalnya dengan memperkuat pola komunikasi formal (dalam pekerjaan) maupun informal (gathering pegawai), meningkatkan pola pertukaran antar atasan dan bawahan (leader member exchange) yang lebih positif. Hal ini ditujukan agar pegawai lebih merasa bahagia dan berkonsentrasi dengan pekerjaannya, sehingga pegawai dapat lebih fokus dalam pekerjaannya serta menunjang pencapaian kinerja baik secara individu maupun institusi.

Selain itu jika ditinjau dari pola atau gaya kepemimpinan di Puslitbang SDA, disarankan agar pimpinan lebih berani dalam mendelegaikan wewenang kepada bawahannya. Secara tidak langsung hal ini dapat mendorong keterikatan seorang bawahan dalam pekerjaan dan atau institusi.

\section{REFERENSI}

Ayuningtias, HG. 2013. Pengaruh High Peformance Work Environment terhadap Employee Engagement dan implikasinya pada kepuasan Kerja dan Kinerja Pegawai [tesis]. Bandung : Universitas Padjadjaran.

Carnegie, Dale. 2012a. Building A Culture of Engagement : The Importance of Senior Leadership. Dale Carnegie \& Associates, Inc. 
Carnegie, Dale. 2012b. What Drives Employee Engagement and Why it Matters.Dale Carnegie \& Associates, Inc.

Demerouti, E. Mostert, K. Bakker, AB. 2010. Burnout and Work Engagement: A Thorough Investigation of the Independency of Both Constructs. Journal of Occupational Health Psychology 15 (3) : 210.

Deviyanti, AD. Sasono, AD. 2015. Pengaruh Sumber Daya Pekerjaan (Job Resources) dengan Keterikatan Kerja (Work Engagement) sebagai Mediator terhadap Perilaku Proaktif. Jurnal Ilmu Manajemen Magistra Vol 1 (1) : 18.

Elmansyah. 2011. Pengaruh Gaya Kepemimpinan terhadap Disiplin Kerja Pegawai Sekretariat Daerah Kota Pekanbaru [tesis]. Pekanbaru : Universitas Islam Riau.

Gallup. 2013. State of The Global Workplace: Employee Engagement Insights For Business Leaders Worlwide. Gallup, Inc.

Jeffrey, I. Hermawan, A. Hubeis, M. Djohar, S. 2011. Pengaruh Kecocokan Gaya Kepemimpinan dan Budaya Organisasi terhadap Kinerja Individu. Jurnal Manajemen \& Agribisnis Vol 8 (2) : 99

Mahardayani, IV. 2010. Efektivitas Situasional Leadership Training pada Section Head. Jurnal Sosial dan Budaya 3 (2): 3-4.

Muliawaty, D. 2014. Pengaruh Employee Engagement dan Gaya Kepemimpinan Transformasional terhadap
Organizational Citizenship Behavior serta Implikasinya pada Intention to Quit [tesis]. Bandung: Universitas Padjadjaran.

Riyadi, S. 2011. Pengaruh Kompensasi Finansial, Gaya Kepemimpinan, dan Motivasi Kerja terhadap Kinerja Pegawai pada Perusahaan Manufaktur di Jawa Timur. Jurnal Manajemen dan Kewirausahaan Vol 13 (1) : 41-42.

Schaufeli, W. Bakker, A. 2003. Utrecht Work Engagement Scale. Utrecht University.

Shane, SLM. Glinow, MAV. 2010. Organizational Behavior 5th Edition. New York : Mc Graw Hill.

Society for Human Resource Management (SHRM). 2013a. A Publication of the Society for Human Resource Management : Workplace Visions. SHRM.

Society for Human Resource Management (SHRM). 2013b. Employee Recognition Survey 2013 : Driving Stronger Performance Through Employee Recognition. SHRM/Globoforce.

Society for Human Resource Management (SHRM). 2014. Workplace Visions. SHRM/Globoforce.

Wirda, F. Azra, T. 2012. Pengaruh Gaya Kepemimpinan Situasional dan Motivasi Kerja terhadap Kepuasan Kerja Pegawai Politeknik Negeri Padang. Jurnal Polibisnis Vol 4 (1) : 26 
Metha Djuwita Supriatna /Jurnal Administrasi Negara, Volume 24 Nomor 2 (2018)/101-114 